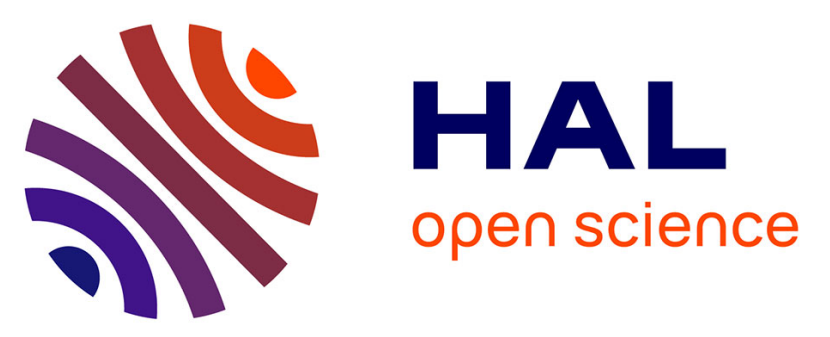

\title{
Microwave assisted extraction of bioactive saponins from the starfish Echinaster sepositus: Optimization by response surface methodology and comparison with ultrasound and conventional solvent extraction
}

\author{
B. Dahmoune, F. Houma-Bachari, M. Chibane, C. Akrour-Aissou, J.-P.
} Guégan, T. Vives, P. Jéhan, F. Dahmoune, L. Mouni, V. Ferrières, et al.

\section{To cite this version:}

B. Dahmoune, F. Houma-Bachari, M. Chibane, C. Akrour-Aissou, J.-P. Guégan, et al.. Microwave assisted extraction of bioactive saponins from the starfish Echinaster sepositus: Optimization by response surface methodology and comparison with ultrasound and conventional solvent extraction. Chemical Engineering and Processing: Process Intensification, 2021, 163, pp.108359. 10.1016/j.cep.2021.108359 . hal-03196096

\section{HAL Id: hal-03196096 https://hal.science/hal-03196096}

Submitted on 21 Apr 2021

HAL is a multi-disciplinary open access archive for the deposit and dissemination of scientific research documents, whether they are published or not. The documents may come from teaching and research institutions in France or abroad, or from public or private research centers.
L'archive ouverte pluridisciplinaire HAL, est destinée au dépôt et à la diffusion de documents scientifiques de niveau recherche, publiés ou non, émanant des établissements d'enseignement et de recherche français ou étrangers, des laboratoires publics ou privés. 


\section{Article}

Microwave assisted extraction of bioactive saponins from the starfish Echinaster sepositus: optimization by response surface methodology and comparison with ultrasound and conventional solvent extraction

Bouchra Dahmoune $e^{\mathrm{a}, \mathrm{b}, \mathrm{c}^{*}}$, Fouzia Houma Bachari ${ }^{\mathrm{a}}$, Mohamed Chibane ${ }^{\mathrm{c}}$, Cherifa Akrour Aissou $^{\mathrm{a}}$, Jean-Paul Guégan ${ }^{\mathrm{c}}$, Thomas Vives $^{\mathrm{c}}$, Philippe Jéhan $^{\mathrm{d}}$, Farid Dahmoune ${ }^{\mathrm{e}}$,Lotfi Mouni ${ }^{\mathrm{b}}$, Vincent Ferrières ${ }^{\mathrm{c}}$, Didier Hauchard ${ }^{\mathrm{c}}$

${ }^{a}$ Laboratory of Marine and Coastal Ecosystems, École nationale des sciences de la mer et de l'aménagement du littoral ENSSMAL, Dély Ibrahim 16320, Alger, Algéria;

${ }^{b}$ Laboratory for the Management and Valorisation of Natural Resources and Quality Assurance, Akli Mohand Oulhadj university of Bouira, Rue Freres Boussendalah, Algeria;

${ }^{c}$ Univ Rennes, École Nationale Supérieure de Chimie de Rennes, CNRS, UMR 6226 - Institut Sciences Chimiques Rennes, Rennes, France;

${ }^{d}$ SCANMAT UMS 2001, CRMPO, Université de Rennes 1, Rennes, France;

${ }^{e}$ Laboratoire de Biomathématique, Biophysique, Biochimie, et Scientométrie (L3BS), faculté des Sciences de la Nature et de la Vie, Université de Bejaia, 06000 Bejaia, Algérie.

*Corresponding author: Bouchra Dahmoune at Laboratory of Marine and Coastal Ecosystems, École nationale des sciences de la mer et de l'aménagement du littoral ENSSMAL, Campus Universitaire de Dely Ibrahim Bois des Cars, Dély Ibrahim 16320, Alger, Algéria.

E-mail address: bouchra.dahmoune@yahoo.fr

Phone number: +213779381003 . 


\section{Graphical abstract}

Microwave assisted extraction of bioactive saponins from the starfish Echinaster sepositus: optimization by response surface methodology and comparison with ultrasound and conventional solvent extraction

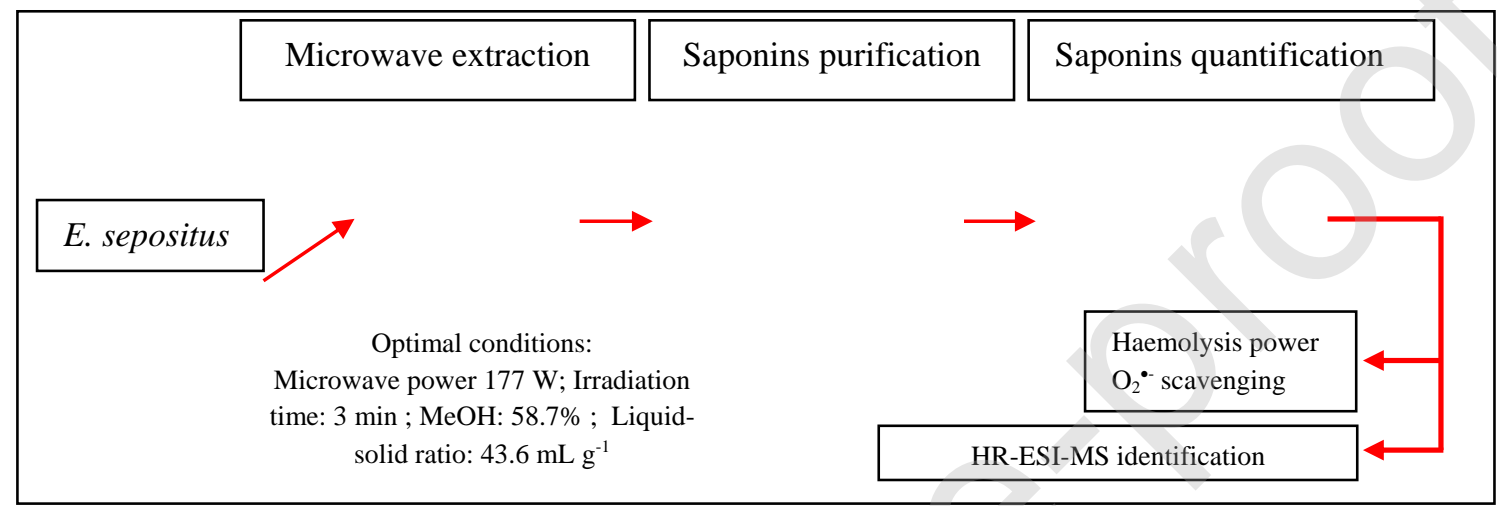

Highlight

- Microwave-assisted extraction was successfully employed to saponins extraction from E. sepositus.

- The effect of each variable was study by applying Box-Behnken design (BBD).

- Optimal conditions: methanol 58.7\%, power $177 \mathrm{~W}$, time $3 \mathrm{~min}$, liquid-solid ratio 43.6 $\mathrm{mL} \mathrm{g}^{-1}$.

- MAE saponin extract was characterized by a 7.82 times higher content compared to CSE. 


\begin{abstract}
Microwave assisted extraction (MAE) was investigated for the extraction of total saponins compounds from the starfish Echinaster sepositus. In order to achieve optimization of microwave extraction and to determine the influence of each operational variable (the solvent concentration (X1), irradiation time (X2), microwave power (X3), and liquid solid ratio (X4)) on the extraction of saponins, response surface methodology (RSM) coupled with a BoxBehnken design (BBD) was applied. The optimized experimental conditions were $58.7 \%$ aqueous methanol as solvent, $177 \mathrm{~W}$ as microwave power for $3 \mathrm{~min}$ irradiation time at 43.6 $\mathrm{mL} \mathrm{g}^{-1}$ of liquid/solid ratio. The extraction yield under these conditions was $60.3 \pm 0.6 \mathrm{mg} \mathrm{g}^{-1}$. The optimized MAE was compared with other methods (ultrasound assisted extraction, UAE) and with conventional solvent extraction (CSE). It was demonstrated that microwave produced saponins extraction 7.8 times as more as that produced by CSE and 3.3 as more as UAE has produced.
\end{abstract}

From the in vitro hemolytic tests and electro-generated $\mathrm{O}_{2}{ }^{\bullet-}$ quenching tests, we have noted that the microwave saponins extract was the most active one comparing with both UAE and CSE extracts. 


\section{Keywords}

Microwave assisted extraction; saponins; optimization; Echinaster sepositus.

\section{Introduction:}

Microwave assisted extraction (MAE) is a green technology which provides rapid energy transfer and simultaneous heating of the biological material and solvent assembly [1]. These characteristics, improve the extraction yield, the reduction of extraction time and the quantity of solvent used $[\mathbf{1}, \mathbf{2}]$. These advantages over conventional extraction techniques make it alternative techniques to extract bioactive natural products. The MAE was used during the past few years as a strategy to improve the recovery of the bioactive natural product. In this regard, the microwave is employed to increase polyphenols, saponins, vegetable oils yield, etc [2-5].

The marine biotechnology seeks for sustainable ways for utilization of marine bioresources (flora and fauna) to produce new high added-value biomolecules. In this context and to limit the impact of the extraction processes on the environment, the green extraction could satisfy the increasing demand for alternative sources of bioactive compounds.

Actually, different alternative techniques or quantitative methods are needed, in the case of marine drugs concerning the sampling difficulty and the type of used matrixes often endemic. These particularities require the adoption of quantitative methods in studies in order to obtain the maximum yield from the low amount of the primary matrix. In this regard, this study aims at enhancing the extraction yield of saponins mixture, from the starfish Echinaster sepositus 
collected in Algerian coasts, through applying microwave-assisted extraction (MAE) technique and optimizing its conditions.

The interest in saponins of this species is justified by their unusual structure, belonging to a rare structure group of marine glycosides which discovered by Italian scientists more than 40 years ago $[6,7]$. This unique compound containing a trisaccharide chain cyclized between $\mathrm{C}-3$ and C-6 of the $\Delta 7-3 \beta, 6 \beta$-dihydroxysteroid aglycone (Fig. 5). On the other hand, starfish saponins are of high pharmaceutical interest due to their, anti-bacterial, anti-fungal, anti-viral and anti-tumor properties [8-12].

To optimize the parameters affecting the MAE of saponins from starfish, the Box-Behnken experimental design (BBD) using response surface methodology (RSM) was applied. BBD is one of the most efficient experiment designs, because it does not allow the combinations for which all factors are simultaneously at their highest or lowest levels. Thus, it is used to avoid experiments performed under extreme conditions. In this study, the following factors have been evaluated: were the solvent concentration (X1), irradiation time (X2), microwave power (X3), and liquid-solid ratio (X4). Based on the response surfaces, optimal conditions of the microwave pretreatment have been determined. Finally, the study has been complemented with a variance analysis (ANOVA), to determine the statistically significant factors. To the best of our knowledge, there is no available literature detail with the optimization of green procedure for the extraction of total saponins compound (TSC) from starfish.

Therefore, the main objectives of the current study can be listed as follows:

- Optimization of MAE procedure by response surface methodology (RSM) for the extraction of total saponins compounds from E. sepositus;

- Studying comparatively the optimized MAE, UAE and the reference CSE methods;

- Using high-resolution mass spectrometry (HR-ESI-SM) to identify the saponins mixture obtained by MAE method. 
- Evaluation of the hemolytic power of the three saponins extracts (MAE, UAE and CSE).

- Evaluation of the antioxidant capacity power of the three saponins extracts (MAE, UAE and CSE) by their ability to scavenge electrochemically-generated superoxide radical $\left(\mathrm{O}_{2}{ }^{\bullet-}\right)$.

\section{Materials and methods}

\subsection{Biological material}

E. sepositus (Retzius, 1783) individuals were collected in summer 2018 from Algerian sea coast between 5 to $10 \mathrm{~m}$ of depth. In total, 28 individuals as samples weighed about $1724 \mathrm{~g}$ were collected and were transported in plastic bags containing sea water. In the laboratory, the starfish individuals were freeze-dried (Alpha-1-2 LD plus freeze-dryer). The lyophilized samples obtained were ground with an electrical grinder and they were stored in dark waterproof tubes inside a desiccator until use.

\subsection{Experimental work design and statistical modelling}

The type of solvent, solvent concentration, irradiation time, microwave power and solid-toliquid ratio were firstly studied separately in single-factor experiments to reduce the number of the total experiments work, and to determine the appropriate interval for each parameter in the design of experiment for microwave assisted extraction - MAE (Table 1). In this preliminary study, the experimental work has been carried out by varying an experimental parameter while all the other parameters were kept constant at their middle values. In the MAE, the type and concentration of solvent effect were studied for the constant values of liquid-solid ratio $\left(20 \mathrm{~mL} \mathrm{~g}^{-1}\right)$, microwave power $(200 \mathrm{~W})$ and irradiation time (5 min). The irradiation time effect was evaluated for a $\mathrm{MeOH}$ concentration of $50 \%$.

The irradiation time was set at $3 \mathrm{~min}$ in the trials to investigate the microwave power influence. This latter was set at $200 \mathrm{~W}$ in the trials to investigate the ratio liquid to solid 
parameter. The response surface methodology (RSM) based on Box-Behnken design (BBD) of three-levels-four-factor experimental was assessed to maximize the saponins yield extracted from E. sepositus using MAE process (Table 2). The design requires a number of experiment trials according to $N=2 k(k-1)+C_{0}$, where $\mathrm{k}$ is the number of factors and $C_{0}$ is the number of center points and each independent factor is studied at three level $(-1,0$ and +1$)$ reference.

The data was analyzed by Minitab.17 with a standard least square in order to obtain RSM.

The ANOVA F test was assessed to adjust models and the coefficient significance at a p-value less than 0.05 (Table 3).

The model used for data regression analysis is corresponding to a second-order polynomial equation (Quadratic model) (Eq. (1)). This equation is then used to predict the optimal extraction conditions.

$$
Y=B_{0}+\sum_{i=1}^{k} B_{i} X_{i}+\sum_{i=1}^{k} B_{i i} X_{i}^{2}+\sum_{i>1}^{k} B_{i j} X_{i} X_{j}+E
$$

where $Y$ represents the total saponin compounds (TSC); $\beta_{0}$ is a constant coefficient; $B_{i}, B_{i i}$ and $B_{i j}$ are the coefficients of the linear, quadratic and interactive terms, respectively, and $X_{i}$ and $X_{j}$ represent the actual independent variables (i-j), $E$ is an error.

Additional experiments of extraction were carried out at the optimal conditions, and the results obtained were compared to the values predicted by the regression model in order to validate the model.

Finally, the extract obtained at the optimal conditions was compared to ultrasound assisted extraction (UAE) and conventional solvent extraction method (CSE). The effects of microwave, ultrasonic and magnetic agitation on the microstructure of the samples powder 
(before and after the different extraction processes) were observed by scanning electron microscopy (SEM).

\subsection{Extraction procedures}

\subsubsection{Microwave-assisted extraction (MAE)}

Microwave-assisted extraction (MAE) was carried out using a multimode microwave oven (NN-S674MF, Samsung, Malaysia) equipped with a digital control system for irradiation time and microwave power. The apparatus is characterized by a frequency of $2450 \mathrm{kHz}$; a maximum output power of $1000 \mathrm{~W}$ with an increment of 100, and a heating cavity dimensions is $22.5 \mathrm{~cm} \times 37.5 \mathrm{~cm} \times 38.6 \mathrm{~cm}$. In order to condensate the vapors generated during extraction, the heating cavity was modified.

Briefly, $1 \mathrm{~g}$ of starfish powder was placed in a flask and an adequate volume of extraction solvent is added. The suspension was irradiated at regular intervals of power and time according to the operation in progress (Tables 1 and 2). The solvent concentration (X1), irradiation time (X2), microwave power (X3), and liquid-solid ratio (X4) for each trial performed are listed in Table $\mathbf{1}$ for the preliminary study and Table $\mathbf{2}$ for extraction optimization.

The extract obtained after microwave irradiation was filtered under vacuum with a Büchner flask through No. 1 Whatman paper. Then the filtrate was evaporated at low pressure in a double boiler at $30^{\circ} \mathrm{C}$ using a rotary evaporator (RE301 - Stuart, UK). The residues were recovered and dissolved in milli-Q water (crude extract) to undergo different purification steps as reported in section 2.4 .

\subsubsection{Ultrasound-assisted extraction (UAE)}

Ultrasonic-assisted extraction (UAE) was carried out by an ultrasonic bath apparatus (SELACTA type) working at 50/60 Hz and $195 \mathrm{~W}$ frequency and power respectively. 
Briefly, $1 \mathrm{~g}$ of starfish powder and $46 \mathrm{~mL}$ of $70 \%$ methanol were placed in a glass bottle. The suspension was exposed to acoustic waves for $25 \mathrm{~min}$. The extract was recovered and analyzed as reported in section 2.4 .

The UAE extraction conditions were selected from a series of 15 experiments including extraction time, solvent concentration in distilled water and liquid-to-solid ratio independent parameters, designed by Response Surface Methodology (RSM) to optimize the recovery of the saponin extraction from E. sepositus.

\subsubsection{Conventional solvent extraction (CSE)}

The saponins extract from starfish powder was extracted using a conventional extraction technique. $1 \mathrm{~g}$ of starfish powder was mixed with $50 \mathrm{~mL}$ of $70 \%(\mathrm{v} / \mathrm{v})$ methanol-water solvent in a $150 \mathrm{~mL}$ glass flask. The mixture was subjected to a magnetic agitator for $24 \mathrm{~h}$ at room temperature.

\subsection{Saponins purification}

The crude extracts obtained by different extraction methods (MAE, UAE and CSE) were purified in order to remove all impurities according to the method reported in the literature $[13]$.

The aqueous crude extract was partitioned by using the liquid-liquid extraction method. Three organic solvents, $n$-hexane $(0.09 \mathrm{D})$, dichloromethane $(1.60 \mathrm{D})$ and chloroform $(1.04 \mathrm{D})$ were conducted respectively to partition crude extract. Saponins were maintained in methanol phase for each one of these extractions [14]. In fact, the aqueous crude extracts were dried by using rotary evaporation (RE301 - Stuart, UK). Then dry extracts were solubilized in $20 \mathrm{ml}$ of methanol $90 \%$ followed by liquid-liquid partitioning in $n$-hexane (v/v) to eliminate lipids and fatty acid. The methanol fractions were recovered and adjusted with water corresponding to $20 \%$ of the methanolic volume. After that, this later was mixed with an equal volume of dichloromethane. After decantation, the dichloromethane fraction was removed and the 
hydromethanolic phase was adjusted with $40 \%$ of water. Then, the liquid-liquid partitioning procedure for a remaining hydromethanolic phase was continued by adding in a separatory funnel a chloroform (v/v) that was stirred and left at rest for three hours minimum. After the sample decantation process, the lower phase was removed and the resulting hydromethanolic upper phase was evaporated under rotary evaporation to evaporate the solvents. Then, the obtained dry extracts were dissolved in $5 \mathrm{ml}$ distilled water which was transferred to chromatography column packed with Amberlite XAD-4 (Sigma- Aldrich St. Louis, MO, USA). The column was then washed with $100 \mathrm{ml}$ of distilled water to remove any organic salts. The absorbed fraction saponins were eluted with $100 \mathrm{ml}$ of methanol.

Finally, the obtained methanolic fractions were evaporated to remove the methanol solvent, the dry extracts were then dissolved in $5 \mathrm{ml}$ of distilled water. The resulting aqueous solution obtained previously was mixed in a separatory funnel with $5 \mathrm{~mL}$ iso-butanol solvent that was blended and left at rest for 2 hours. After this period, the upper saponins-rich phase was separated from lower phases, then, the ios-butanol solvent was evaporated in a rotary evaporator. Finally, the dry recovered extract was dissolved in distilled water and lyophilized.

\subsection{Determination of total saponins compound yield}

The saponins amount of each extract was determinate according to the Food Standard Code [15]. In fact, the round bottom flask was dried at $105^{\circ} \mathrm{C}$, cooled in desiccator, and weighed to a constant weight before its freeze-drying. Once the lyophilization was completed, the flasks were weighed for a second time; the difference in weights corresponds to the total saponin amount in the sample ( $\mathrm{mg}$ Tsap). The saponins were recovered in the form of white residues. The total saponins compound yield (TSC) is expressed in $\mathrm{mg} \mathrm{g}^{-1}$ and calculated from the total saponin amount $\left(\mathrm{T}_{\mathrm{sap}}\right)$ and the initial dried starfish powder dry, according to the following equation (Eq. (2)):

$$
\operatorname{TSC}\left(\mathrm{mg} \mathrm{g}^{-1}\right)=\frac{\mathrm{mg} \text { Tsap }}{\text { g starfish powder }}
$$




\subsection{Hemolytic activity}

The hemolytic power of saponins obtained from MAE, UAE and CSE was evaluated according to the method described by Apers et al. [16]. Citrated blood from the horse was used in this experiment. Erythrocytes were isolated from the various constituents of the blood by washing four times in cold PBS buffer $\left(138 \mathrm{mM} \mathrm{NaCl}, 2.7 \mathrm{mM} \mathrm{KCl}, 1.5 \mathrm{mM} \mathrm{KH}_{2} \mathrm{PO}_{4}, 8.1\right.$ $\left.\mathrm{mM} \mathrm{Na}_{2} \mathrm{HPO}_{4}, \mathrm{pH} 7.4\right)$ and centrifuged during $15 \mathrm{~min}(10000 \mathrm{rpm})$ until the supernatant was clear and colorless. The supernatant was removed and two milliliters of packed cells were diluted to $100 \mathrm{~mL}$ with the PBS buffer to obtain erythrocyte suspension at $2 \%$. A volume of $1980 \mu \mathrm{L}$ of the erythrocyte suspension was added to $20 \mu \mathrm{L}$ of saponins extract in a microtube. The suspension was mixed, incubated for $6 \mathrm{~h}$ at room temperature and centrifuged (1000 rpm) for $10 \mathrm{~min}$. The supernatant was recovered and its absorbance was measured at $540 \mathrm{~nm}$ using a spectrophotometer (model 7305, JENWAY).

The hemolytic capacity was expressed as percentage of lysed erythrocytes, and calculated according to the following equation (Eq. (3)):

$$
\% \text { hemolysis }=\frac{A b s_{\text {sample }}-A b s_{\text {control }}}{A b s_{\text {total hemolysis }}} \times 100
$$

where Abs sample is the absorbance of erythrocyte suspension $(1980 \mu \mathrm{L})+$ sample extract $(20$ $\mu \mathrm{L})$; Abscontrol is the absorbance of negative control solution containing erythrocyte suspension $(1980 \mu \mathrm{L})+$ PBS buffer $(20 \mu \mathrm{L})$; Abstotal hemolysis is the absorbance of $20 \mu \mathrm{L}$ erythrocyte suspension obtained from negative control solution+ milli-Q water (1980 $\mu \mathrm{L})$.

From data elaboration ( $\%$ hemolysis plotted versus saponins concentration), the concentration of TSC required to lyses $50 \%$ of erythrocyte ( $\left.\mathrm{IC}_{50}\right)$ was calculated.

2.7. Antioxidant activity by electro-generated $\mathrm{O}_{2}{ }^{\bullet-}$ quenching 
The antioxidant activity of the extracts (MAE, UAE, CSE) was measured in-vitro using electro-generated $\mathrm{O}_{2} \bullet^{-}$(anion superoxide radical).

This method has been developed by Le Bourvelec et al. [17]. It was applied to different plant. extracts as phenolic compounds [18-21]. In this study, we applied it for marine extract, for the first time.

This method is based in a kinetics reaction of the antioxidant substrate, present in the extract, with the superoxide radical $\mathrm{O}_{2}{ }^{\circ-}$ generated by oxygen reduction in an aprotic medium (N, N-dimethylformamide (DMF) extra dry).

The redox system $\mathrm{O}_{2} / \mathrm{O}_{2}{ }^{*}$ is reversible under these conditions. The addition of increasing amounts of antioxidant decreases the peak oxidation of $\mathrm{O}_{2}{ }^{\circ}$, showing a tendency to loose the reversibility of the redox system. The reactivity of the radical $\mathrm{O}_{2}{ }^{-}$is directly measured at the backward scan by the decay of the anodic current from its oxidation in the presence of extract (Fig. S. 1).

All electrochemical assays were carried out by a cyclic voltammetric technique using a dual potentio-galvanostat (PGSTAT 30, Autolab instrument, Eco Chemie B.V., Utrecht, The Netherlands), controlled by a GPES software (version 4.9, Eco Chemie B.V.). All measurements were carried out on a three-electrode thermostated cell. The following electrodes were used: a glassy carbon disk working electrode (diameter $2 \mathrm{~mm}$ ), a platinum wire counter electrode, and a reference electrode $\mathrm{Ag} / \mathrm{AgCl}$ in $\mathrm{EtOH}$ saturated with $\mathrm{KCl}$. The reference electrode was separated from the solution by a salt bridge containing $0.2 \mathrm{~mol} \mathrm{~L}^{-1}$ of tetrabutylammonium hexafluorophosphate $\left(\mathrm{Bu}_{4} \mathrm{NPF}_{6}\right)$ in DMF.

To perform analysis the electrochemical cell was adjusted at $20.0 \pm 0.2^{\circ} \mathrm{C}$. This cell contains $10 \mathrm{~mL}$ of an extra dry DMF containing the supporting electrolyte $0.1 \mathrm{~mol} \mathrm{~L}^{-1} \mathrm{Bu}_{4} \mathrm{NPF}_{6}$ saturated by dry air during $10 \mathrm{~min}$. The cyclic voltammogramm (CV) of the oxygen reduction was then recorded at a scan rate $0.1 \mathrm{~V} / \mathrm{s}$, with the initial potential at $0.6 \mathrm{~V}$ and the reverse one 
at $-1.23 \mathrm{~V}$ versus reference electrode, in order to obtain the intensities of the initial cathodic and anodic peak currents (Ipc 0 and Ipa0, respectively) before addition of antioxidant in the cell (Fig. S. 1).

To the $10 \mathrm{~mL}$ oxygen solution an aliquot of saponins solutions $\left(1 \mathrm{mg} \mathrm{mL}^{-1}\right)$ were successively added to get an increasing of saponins concentration. After each addition, the CV plot of the cell solution was recorded to obtain a precise and significant evolution of the intensities of the anodic peak current $\left(\mathrm{Ipa}_{\mathrm{s}}\right)$.

In this study, ascorbic acid, well known for its antioxidant properties, was used as a positive control and the antioxidant index used to evaluate the antioxidant activity is AI50, defined as extract concentration needed to consume 50\%, of the electro generated radical corresponding to $(\mathrm{Ipa} 0-\mathrm{Ipas}) / \mathrm{Ipa} 0=0.5$. To estimate $\mathrm{AI}_{50}$ the variation of $(1-\mathrm{Ipas} / \mathrm{Ipa} 0)$ were plotted according to the concentration of added saponins (Fig. 5).

For the measurements of the decreasing of oxidation peak current of $\mathrm{O}_{2}{ }^{\bullet}$ in presence of extract we adopted the method used by Guendouze et al. [21] which aims at exploiting the convolution time semi-derivative transformation of cyclic voltammograms. Indeed, for convolution curves, the baselines are easier to define automatically in comparison with the asymmetric cyclic voltammetric curves and the oxidation peak current values, before and after extract additions, can be more accurately measured (Fig. S. 1).

\subsection{Identification of saponins by ESI-HR-MS measurements}

In order to confirm the molecular weight of saponins, extract by MAE from E. sepositus, high resolution mass spectrometry experiments (HR-ESI-MS) were performed on a Thermo Fisher Scientific Q-Exactive mass spectrometer, in both positive and negative ionization modes by direct infusion. MS experiments were performed at the higher resolution of the instrument (140,000 at $\mathrm{m} / \mathrm{z} 200)$. Elementary compositions of the ions were determined using instrument software (Xcalibur). 
The MAE extract was prepared using a concentration of $10-20 \mu \mathrm{g} \mathrm{mL}^{-1}$ and the flow rate was

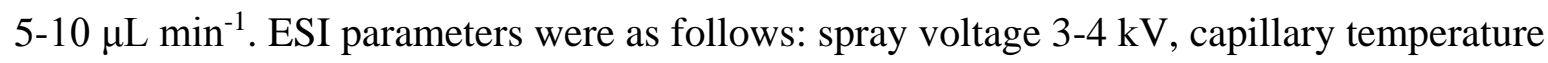
$300^{\circ} \mathrm{C}$, sheath gas flow rate 10-80, auxiliary gas flow 0-10, SLens RF Level 100.

The single-stage ESI-MS spectra were recorded by scanning 150-2000 m/z mass range.

\subsection{Statistical analysis}

In our work all experiments were carried out in triplicate and the results have been reported as means \pm SD.

The analysis of the influence of the single-factor experiment, of the data obtained from the BBD trials and the influence of extraction technique (MAE, UAE or CSE) on total saponins compound (TSC) yield, was statistically assessed by ANOVA and Tukey's posthoc test for means discrimination (95\% confidence level).

To test the model significance for the MAE the data obtained from BBD for the response variable were statistically analyzed using ANOVA. The model was taken significant and highly significant at $\mathrm{p}<0.05$ and $\mathrm{p}<0.01$, respectively.

The Minitab software was used to construct the BBD experimental design and to analyze all the results.

3. Results and discussion

\subsection{Microwave-assisted extraction}

\subsubsection{Single-factor experiments}

The saponins recovery and the experimental conditions of the various TSC values are summarised in Table 1. It can be observed, that the higher values of TSC correspond to the aqueous methanol $\left(24 \mathrm{mg} \mathrm{g}^{-1}\right)$.

Table 1 shows, that TSC yield increase when methanol percentage increases from 20 to $50 \%$ at constant microwave power, extraction time and liquid-solid ratio. These results mean that at 
higher methanol concentrations, absorbed microwave energy increases, consequently, the solvent power to dissolve saponins also increases.

Eskilsson et al. (2000) reported that the differences of TSC yield are attributed to the difference in dielectric properties of the solvent which significantly influence the ability of a solvent to absorb microwave energy [1].

Methanol has a high dissipation factor $\left(\tan \delta=640010^{-4}\right)$, and a relatively high dielectric constant $\left(\varepsilon^{\prime}=33.62\right)$ [1]. Hence, the aqueous methanol can be considered as appropriate solvent for saponins extraction from starfish by MAE.

A methanol 50\% (v/v) was set for the next single-factor experiments and the range of 30 to $70 \%(\mathrm{v} / \mathrm{v})$ was selected for the optimization of MAE by the RSM.

Concerning the effect of irradiation, the TSC increased significantly from 39 to $55 \mathrm{mg} \mathrm{g}^{-1}$ between 1 to $3 \mathrm{~min}$, and decreases at longer irradiation times $(4-8 \mathrm{~min})$ with a highly significant difference (Table 1). In fact, longer irradiation by microwave induces probably thermal degradation of bioactive compounds $[15,22]$. The range of 1 to 5 min has been selected for the optimization of saponins extraction by MAE.

In case of microwave power, the TSC yield increased significantly as microwave power has increased from 100 to $200 \mathrm{~W}$, then decreased with rising microwave power in tested conditions (Table 1). This effect of microwave power on TSC yield could be due to its heating effect, which induces increase of mass transfer phenomena, up to a certain microwave power value, and then thermal degradation of bioactive compounds at higher microwave power $[15,22]$. According to the obtained results, the $200 \mathrm{~W}$ power have been used for the last single-factor trials, while the range 100-300 W was selected for the RSM study.

Table 1 shows that the ratio liquid-solid significantly affected the TSC values, in way that as increasing liquid-solid ratio from 10 to $40 \mathrm{~mL} \mathrm{~g}^{-1}$, the TSC yield raised significantly, however higher volumes failed to increase TSC yield. This result can be explained by the fact that, the 
solvent volume must be just sufficient to immerse the entire sample [1]. The adequate volume of solvent increases the concentration gradient to drive the mass transfer. Based on statistical analysis, the range of 20 to $50 \mathrm{~mL} \mathrm{~g}^{-1}$ was selected for the RSM optimization.

\subsubsection{Response surface methodology optimization of operating parameters}

The response surface methodology (RSM) optimization has been directed to the TSC compounds involved in this present work. The experimental values of the TSC obtained from BBD trials and the corresponding predicted values according to the applied second-order regression model are shown in Table 2. The statistical analysis (ANOVA) appropriate to the second order model (Eq. (1)) is reported in Table 3.

The ANOVA analysis demonstrated that the interaction term extraction time and ratio $\left(\mathrm{X}_{2} \mathrm{X}_{4}\right)$ was not significant ( $p>0.399)$, the other linear terms, quadratic and interaction was highly significant $(\mathrm{p}<0.01)$, hence the mathematical model (Eq. (4)) correlating the recovery of TSC with MAE process variables is given below excluding non-significant terms: $\mathrm{mg} \mathrm{g}^{-1}$.

$$
\begin{aligned}
Y \operatorname{sap}\left(\mathrm{mg} \mathrm{g}^{-1}\right) & =191.66+3.5527 X_{1}+26.56 X_{2}+0.32 X_{3}+3.65 X_{4}-0.0597 X_{1} X_{2} \\
& -0.0001 X_{1} X_{3}+0.0089 X_{1} X_{4}-0.0112 X_{2} X_{3}-0.0022 X_{3} X_{4}-0.03287 X_{1}^{2} \\
& -3.5182 X_{2}^{2}-0.0005 X_{3}^{2}-0.0433 X_{4}^{2}
\end{aligned}
$$

To determine whether the accuracy of mathematical model, the ANOVA analysis was conducted. The results of the statistical analysis of the second order model fitting are illustrated in Table 3. The ANOVA demonstrated that the model was highly significant.

The determination coefficient $\left(\mathrm{R}^{2}\right)$ value of 0.9998 indicates that only $0.02 \%$ of the total variations was not explained by the model. In addition, the adjusted determination coefficient $\left(R^{2}\right.$ adj $\left.=0.9997\right)$ is too close to $R^{2}$. Moreover, the value of $R^{2}$ predicted is 0.9996 , it is in 
agreement with the value of $\mathrm{R}^{2}$ adj. All of these figures confirm that the model is highly significant.

The lack of fit test indicates that the fitting model is adequate to describe the experimental data with the value of lack of fit test of 0.215 higher than 0.05 and not significant relative to the pure error.

Equation (4) was used to generate the three-dimensional response surface plots (Fig. 1). The plots were obtained by plotting the in the Z-axis the TSC against two independent variables drawn in $\mathrm{X}$ and $\mathrm{Y}$-axes, respectively, while keeping the other independent variables at their zero level.

The amount of saponins increased significantly with the increasing methanol concentration from $30 \%$ to around $60 \%$, then decreased significantly as methanol concentration increased from 60 to $70 \%$ at all time in the range from 1 to 6 min (Fig. 1a), as microwave power increased from 100 to $200 \mathrm{~W}$ (Fig. 1b) and as solvent-solid ratio increased from 20 to $45 \mathrm{~mL}$ $\mathrm{g}^{-1}$ (Fig. 1c). These results indicate that methanol concentration is a critical factor to be taken in the extraction of saponins from starfish by MAE because of its implications on the solubility of target compounds, on the microwave absorbing properties and on the interaction between solvent and matrix. The decrease in the TSC with the increase in solvent concentration beyond $60 \%$ can be explained by the change in solvent polarity which leads to the extraction of other compounds than saponins, which may give lower recoveries of saponins. Additionally, the presence of a suitable water proportion in solvent facilitates and improves extraction efficiency by promoting swelling of matrix, which is favorable to increase the contact surface area between the matrix and the solvent [23].

The important amount of saponins obtained by increasing microwave power from 100 to 200 $\mathrm{W}$ and the time from 1 to 3 min (Fig. 1d) can be explained by the temperature generated 
under these operating conditions. These temperature improved extraction efficiency. In fact, with increasing temperature the solvent capacity to solubilize analytes increase, while surface tension and solvent viscosity decrease, such conditions improve sample wetting and matrix penetration of solvent to desorb analytes from active sites in the matrix $[\mathbf{1 , 2 3 ]}$.

Using the power range 100 to $300 \mathrm{~W}$ and higher irradiation time than $3 \mathrm{~min}$, we obtained the lower amount of saponins (Fig. 1d). This result can be attributed to the increase in temperature induces by increment power and irradiation time. Higher induced temperature causes thermal degradation of saponins $[\mathbf{1 , 2 2 , 2 3 ] .}$

The adequate liquid - solid ratio for the extraction of saponins by MAE varies between 40 and $45 \mathrm{~mL} \mathrm{~g}^{-1}$ for an irradiation time within the range from 2 to $3 \mathrm{~min}$ (Fig. 1e) and a power range of 150 to $200 \mathrm{~W}$ (Fig. 1f). On the other hand, the response surface (Fig. 1e and Fig. 1f) indicated that in the same conditions the extraction yields decreased for a ratio of solvent to material of $50 \mathrm{~mL} \mathrm{~g}^{-1}$. This result can be explained by the fact that solvent absorb more microwave irradiation power, leading to the dissipation of microwave energy [23]. The optimal conditions obtained for MAE process of saponins were: methanol concentration, ratio liquid-to-solid, microwave power and irradiation time of $58 \%, 43 \mathrm{~mL} \mathrm{~g}^{-1}, 176.8 \mathrm{~W}$ and 3 min, respectively.

The predicted saponins content under these conditions was $60.83 \mathrm{mg} \mathrm{g}^{-1}$. The results suggested that methanol in this condition could offer the suitable vapor pressure, viscosity and surface tension of extraction solvent for the saponin-enriched extract.

In conclusion, carrying out the optimized MAE produced a saponins yield of $60.3 \pm 0.6 \mathrm{mg} \mathrm{g}$ ${ }^{1}$, that is very close to the value predicted which confirms the validity of the model (Eq. (4)).

\subsection{Comparison between MAE, UAE and CSE}

The efficiency of extraction using MAE was compared to other emerging extraction techniques (UAE and CSE). 
Considering the optimal conditions, the results show that MAE was able to give a higher yield of saponins $\left(60.3 \pm 0.6 \mathrm{mg} \mathrm{g}^{-1}\right)$, followed by the UAE with $\left(18.5 \pm 0.2 \mathrm{mg} \mathrm{g}^{-1}\right)$, and the CSE $(7.7$ $\left.\pm 0.2 \mathrm{mg} \mathrm{g}^{-1}\right)(<0.005)$. In addition, the extraction duration of MAE (3 min) was shorter than that of UAE (25 min) or CSE (24 h). From the results we can deduce that extraction efficiency by microwave was 7.8 times more than UAE extraction and was 3.3 times more than CSE extraction.

According to SEM observations after MAE, UAE and CSE (Fig. 2), we found that the three extraction processes produced changes with different extent on the physical structure of all samples. The sample after MAE was greatly destroyed suggesting that microwave irradiation played an important role in breaking up animal cell walls, rapidly releasing its content.

The low saponin yields obtained by UAE and CSE can be explained by the moderate effect of ultrasound energies and magnetic agitation on cell wall rupture (Fig. 2), this suggests that no severe fracture on starfish powder was caused during the extraction processes. In addition, the surface of the samples after UAE and CSE could be not destroyed suggesting an insignificant role in breaking up starfish cell walls.

The longer extraction time in UAE and CSE submits the extract to unfavorable conditions such as light, and oxygen. Moreover, the ultrasonication could induce free radicals formation within the liquid medium, thus causing oxidation and degradation of the active compounds [24].

From the in vitro hemolytic tests, we noted that MAE extract is the most active with lower $\mathrm{IC}_{50}\left(\mathrm{IC}_{50}=279.9 \pm 2.8 \mu \mathrm{g} \mathrm{mL}^{-1}\right)$ followed by UAE saponins extracts $\left(\mathrm{IC}_{50}=303.5 \pm 1.7 \mu \mathrm{g} \mathrm{mL}^{-}\right.$ $\left.{ }^{1}\right)$ and the CSE saponins extract $\left(\mathrm{IC}_{50}=323.1 \pm 1.2 \mu \mathrm{g} \mathrm{mL}^{-1}\right)$ (Fig. S. 2). This result showed that MAE as the best technology to extract hemolytic active saponins from E. sepositus. The radical quenching of $\mathrm{O}_{2}{ }^{\bullet-}$ represent second-order polynomial model. A determination example of $\mathrm{AI}_{50}$ by electrochemistry methods (for $\mathrm{O}_{2}^{-}$) was represented in Fig. 3. 
The concentrations of MAE, UAE, CSE extract required to quench $50 \%$ of $\mathrm{O}_{2}{ }^{\bullet-}$ radicals, Increase in the following order: CSE $\left(166.7 \pm 0.5 \mathrm{mg} \mathrm{L}^{-1}\right)<\mathrm{UAE}\left(139.8 \pm 0.6 \mathrm{mg} \mathrm{L}^{-1}\right)<\mathrm{MAE}$ $\left(116.2 \pm 0.5 \mathrm{mg} \mathrm{L}^{-1}\right)$.

These results indicated that as the potential antioxidant agent $E$. sepositus saponins exhibited the marked scavenging against superoxide radical and could be widely applied to decrease oxidant forces and increase antioxidant capacity. This activity is never recorded in the literature for these molecules.

\subsection{Identification of saponins by mass spectrometry}

The mass spectra of MAE extract was operated in both positive and negative ion modes by HR-ESI-MS to confirm molecular weight of saponins. Identification of saponins was more evident in the positive ion mode than in the negative one (spectra not shown), they were detected with greater sensitivity and showed intense signals in the m/z 800 and 1000 range which could correspond to ionized $[\mathrm{M}+\mathrm{Na}]^{+}$saponins (Fig. 4).

More saponins components were detected in E. sepositus. The saponin ions presenting the highest relative intensity in the mass spectrum was observed at $\mathrm{m} / \mathrm{z} 921.4453$, followed by $\mathrm{m} / \mathrm{z}$ 891.4349. The m/z $921.4453\left[\mathbf{C}_{45} \mathbf{H}_{70} \mathbf{O}_{18} \mathbf{~ N a}\right]^{+}$(Fig. 5, (1): A, B, C) may correspond to the sepositoside A, major saponin of E. sepositus. The structural characteristics of sepositoside A are the presence of three saccharides in the glycone part cyclized between C-3 and C- 6 of the aglycone; the presence of a glucuronic acid on the oligosaccharide unit to the aglycone moiety and the omnipresence of an aglycone of type $\Delta 7,8-3 \beta, 6 \beta$-dihydroxysteroide $\Delta 7,8$-3 $\beta, 6 \beta$-dihydroxysteroid (8-hydroxy-6-cholesta-8,14-dien-23-one) [25].

The signal $\mathrm{m} / \mathrm{z} 891.4349\left[\mathrm{C}_{44} \mathrm{H}_{68} \mathrm{O}_{17} \mathrm{Na}\right]^{+}$could be associated to a saponin never observed for E. sepositus. This saponin possesses the same mass $(\mathrm{m} / \mathrm{z})$ and raw formula as the luzonicoside 
saponin identified in E. Luzonicus [26, 11] (Fig. 5, (3): A, B, C). Luzonicoside A is different from sepositoside A in the glycone moiety composed of glucuronic acid, arabinose, and galactose [26].

The mass $\mathrm{m} / \mathrm{z} 907.4298\left[\mathbf{C}_{\mathbf{4 4}} \mathbf{H}_{\mathbf{6 8}} \mathbf{O}_{\mathbf{1 8}} \mathbf{N a}\right]^{+}$could correspond to the minor saponin of $E$. sepositus (Fig. 5, (2)). Other, additional signals, m/z $935.4607\left[\mathbf{C}_{\mathbf{4 6}} \mathbf{H}_{72} \mathbf{O}_{18} \mathbf{~ N a}\right]^{+}, \mathrm{m} / \mathrm{z}$ 919.4299 [ $\left.\mathbf{C}_{\mathbf{4 5}} \mathbf{H}_{\mathbf{6 8}} \mathbf{O}_{\mathbf{1 8}} \mathbf{N a}\right]^{+}$could correspond to a new saponin composition never observed before in E. sepositus.

\section{Conclusion}

The optimization of MAE for extracting saponins from E. sepositus by response surface methodology achieves a significant second-order polynomial models, with regression coefficient of 0.99 .

The comparative study demonstrated that the alternative methods MAE and UAE appeared to be better than CSE, allowing higher recovery yield with a shorter extraction time and a lower solvent consumption. MAE was found to be the most efficient method for the extraction of saponins from E. sepositus with enhanced and increased yield in 3 min extraction time. According to the SEM observation it seems that microwave irradiation causes intense tissue degradation.

From hemolytic test and antioxidant activity by electro-generated $\mathrm{O}_{2}{ }^{--}$quenching, it could be concluded that MAE extract exhibited superior in vitro activity comparing to UAE and CSE extract.

The HR-ESI-MS was successfully used to analyze the MAE crude saponins, intense signals are observed, some of them (m/z 921.4453) could correspond to the compositions already identified in E. sepositus and the others (m/z 891.4349) may refer to new saponins (not observed before in E. sepositus). 
Finally, it should be noted that it is the first time that a study on the optimization and comparison of MAE procedure for the extraction of saponins compounds from starfish.

\section{Author contributions}

Fouzia Houma Bachari, Didier Hauchard, Mohamed Chibane and Vincent Ferrières designed the study. Bouchra Dahmoune, Jean-Paul Guégan, Thomas Vives, and Philippe Jéhan performed the experiments. Farid Dahmoune and Lotfi Mouni participated in study design, data collection and analysis. Bouchra Dahmoune and Farid Dahmoune wrote the manuscript Cherifa Akrour Aissou with the authors revised the manuscript.

\section{Conflicts of Interest}

The authors declare no conflict of interest.

\section{Acknowledgments}

We would like to express our sincerest thanks to the Algerian Ministry of Education and Scientific Research, and Campus France for their scholarship within the framework of Algerian-French cooperation PROFAS B+.

We thank the staff of the laboratories who participated in the realization of this works particularly Isabelle Soutrel for their valuable technical assistance and support, and for providing facilities to realize this search. 


\section{References}

[1] C.S. Eskilsson, E. Bjorklund, Analytical-scale microwave-assisted extraction, J.

Chromatog. A. 902 (2000) 227-250, https://doi.org/ 0.1016/s0021-9673(00)00921-3.

[2] J.H. Kwon, J.M.R. Bélanger, J.R.J. Pare, V.A. Yaylayan, Application of the microwaveassisted process (MAPTM) to the fast extraction of ginseng saponins, Food Res. Int. 36 (2003) 491-498, https://doi.org/10.1016/S0963-9969(02)00197-7.

[3] F. Dahmoune, L. Boulekbachea, K. Moussia, O. Aouna, G. Giorgia Spignob, K. Madani, Valorization of Citrus limon residues for the recovery of antioxidants: Evaluation and optimization of microwave and ultrasound application to solvent extraction, Ind. Crops Prod. 50 (2013) 77-88, https://doi.org/10.1016/j.indcrop.2013.07.013.

[4] F. Dahmoune, G. Spigno, K, Moussai, H. Remini, A. Cherbal, K, Madani, Pistacia lentiscus leaves as a source of phenolic compounds: Microwave-assisted extraction optimized and compared with ultrasound-assisted and conventional solvent extraction, Ind. Crops Prod. 61 (2014) 31-40, https://doi.org/10.1016/j.indcrop.2014.06.035.

[5] B.F. Achachlouei, S.Y. Azadmard-Damirchi, Z.R. Shaddel, Microwave pretreatment as a promising strategy for increment of nutraceutical content and extraction yield of oil from milk thistle seed, Ind. Crop. Prod. 128 (2019) 527-533, https://doi.org/10.1016/j.indcrop. 2018.11.034.

[6] F. De Simone, A. Dini, E. Finamore, L. Minale, C. Pizza, R. Ruccio, F. Zollo, Starfish saponins. Part 5. Structure of seposituside A, a novel steroidal Glycoside from the starfish Echinaster sepositus, J. Chem. Soc. Perkin Trans. I (1981) 1855-1862, https://doi.org/ $10.1039 / \mathrm{p} 19810001855$. 
[7] R. Riccio, F. De Simone, A. Dini, L. Minale, C. Pizza, F. Senatore, F. Zollo, Starfish saponins VI-unique. 22, 23-epoxysteroids, Cyclic Glycoside, Minor constituents from Echinaster sepositus, Tetrahedron. lett. 22 (16) (1981) 1557-1560, https://doi.org/10.1016/S0040-4039(01)90377-6.

[8] K. Hostettmann, A. Martson, Chemistry \& Pharmacology of Natural Products. Saponins, (1995), Cambridge University Press. New York.

[9] M.S. Maier, Biological activities of sulfated glycosides from echinoderms, Stud. Nat. Prod. Chem. 35 (2008) 311-354, https://doi.org/10.1016/S1572-5995(08)80008-7.

[10] H.F. Tang, H.Y. Yi, L. Li, P. Sun, S.Q. Zhang, Y.P. Zhao, Bioactive Asterosaponins from the Starfish Culcita novaeguineae. J. Nat. prod. 68(2005) 337-34, https://doi.org/10.1021/np0401617.

[11] A.A. Kicha, A.I. Kalinovsky, T.V. Malyarenko, N.V. Ivanchina, P.S. Dmitrenok, E.S. Menchinskaya, E.A. Yurchenko, E.A. Pislyagin, D.L. Aminin, T.T.T. Huong, F.Q. Long, V.K. Stonik, Cyclic Steroid Glycosides from the Starfish Echinaster luzonicus: Structures and Immunomodulatory Activities, J. Nat. prod. 7 (2015) 1397-1405, https://doi.org/ 10.1021/acs.jnatprod.5b00332.

[12] O.S. Malyarenko, S.A. Dyshlovoy, A.A. Kicha, N.V. Ivanchina, T.V. Malyarenko, B. Carsten, V.A. Gunhild, V.A. Stonik, S.P, Ermakova, The Inhibitory activity of Luzonicosides from the Starfish Echinaster luzonicus against Human Melanoma Cells, Mar drugs. 15 (277) (2017) 2-11, https://doi.org/10.3390/md15070227.

[13] S. Van Dyck, P. Gerbaux, P. Flammang, Elucidation of molecular diversity and body distribution of saponins in the sea cucumber Holothuria forskali (Echinodermata) by mass spectrometry, Comp. Biochem. Physiol. 152 (2) (2009) 124-134, https://doi.org/10.1016/j.cbpb.2008.10.011. 
[14] D.R. Lide, CRC Handbook of Chemistry and Physics: a ready-reference book of chemical and physical data, (2009), Edition CRC Press. London.

[15] J.H. Kwon, J.M.R. Bélanger, J.R.J. Paré, V.A. yaylayan, Application of the microwaveassisted process (MAP ${ }^{\mathrm{TM}}$ ) to the fast extraction of ginseng saponins, Food .Res Int. 36(5) (2003) 491-498, https://doi.org/10.1016/S0963-9969(02)00197-7.

[16] S. Apers, S, Baronikova, J.B. Sindambiwe, M. Witvrouw, E.D. Clercq, D.V. Berghe, E.V. Marck, A. Vlietinck, L. Pieters, Antiveral, Haemolytique and molluscidal activities of triterpénoïde saponins from Maesa lanceolata. Establishment of structure-Activity relationships, Planta. Med. 67(2001) 528-532, https://doi.org/10.1055/s-2001-16489.

[17] C. Le Bourvelec, D. Hauchard, A. Darchen, J.L. Burgot, M.L. Abasq, Validation of a new method using the reactivity of electrogenerated superoxide radical in the antioxidant capacity determination of flavonoids, Talanta, 75 (4) (2008) 1098-1103, https://doi.org/10.1016/j.talanta.2008.01.007.

[18] A. René, M.L, Abasq, D. Hauchard, P. Hapiot, How do phenolic compounds react toward superoxide? A simple electrochemical method for evaluating antioxidant capacity, Anal. Chim. 82 (2010) 8703-8710, https://doi.org/10.1021/ac101854w.

[19] N. Blanc, D. Hauchard, L. Audibert, E. Ar Gall, E, Radical-scavenging capacity of phenol fractions in the brown seaweed Ascophyllum nodosum: an electrochemical approach", Talanta. 84 (2011) 513-518, https://doi.org/10.1016/j.talanta.2011.01.034.

[20] F. Brahmi, D. Hauchard, N. Guendouze, K. Madani, M. Kiendrebeogo, L. Kamagaju, C. Stevigny, M. Chibane, P. Duez, Phenolic composition, in vitro antioxidant effects and tyrosinase inhibitory activity of three Algerian Mentha species, Ind.Crop.Prod. 74 (2015) 722-730, https://doi.org/10.1016/j.indcrop.2015.04.038.

[21] B.N. Guendouze, K. Madani, M. Chibane, M.L. Boulekbache, D. Hauchard, M. 
Kiendrebeogo, C. Stevign, P.N. Okusa, P. Duez, Phenolic compounds, antioxidant and antibacterial activities of three Ericaceae from Algeria, Ind Crops Prod. 70 (2015) 459-466, https://doi.org/10.1016/j.indcrop.2015.03.053.

[22] Z. Hu, M. Cai, H.H. Liang, Desirability function approach for the optimization of microwave-assisted extraction of saiko saponins from Radix Bupleuri, Sep. Purif. Technol. 6 (2008) 266-275, https://doi.org/10.1016/j.seppur.2007.10.016.

[23] J. Li, Y.G. Zu, Y.J. Fu, Y.C. Yang, Li, S.M. Li, Z.N. Li, M. Wink, Optimization of microwave-assisted extraction of triterpene saponins from defatted residue of yellow horn (Xanthoceras sorbifolia Bunge.) kernel and evaluation of its antioxidant activity, Innov. Food Sci. Emerg. Technol. 11(2010) 637-643, https://doi.org/10.1016/j.ifset.2010.06.004.

[24] K. Hayat, S. Hussain, S. Abbas, U. Farooq, B. Ding, S. Xia, C. Jia, X. Zhang, W. Xia, Optimized microwave-assisted extraction of phenolic acids from citrus mandarin peels and evaluation of antioxidant activity in vitro, Sep. Purif. Technol. 70 (2009) 63-70, https://doi.org/10.1016/j.seppur.2009.08.012.

[25] L. Minale, R. Riccio, F. De Simone, A. Dini, C. Pizza, E. Ramundo, Strafish saponins I. 3 $\beta$-HYDROXY-5- $\alpha$-CHOLESTA-8, 14-DIEN-23-ONE, The major genin from STARFISH Echinaster sepositus,Tetrahedron Lett. 19 (29) (1978), 2609-2612, https://doi.org/10.1016/S0040-4039(01)94842-7.

[26] R. Riccio, A. Dini, L. Minale, C. Pizza, F. Zollo, T, Sevenet, Starfish saponins VII. Structure of luzonicoside, a further steroidal cyclic glycoside from the pacific starfish Echinaster luzonicus ${ }^{1,2}$, Experientia. 38 (1982) 68-70, https://doi.org/10.1007/BF01944532. 


\section{Figure captions}
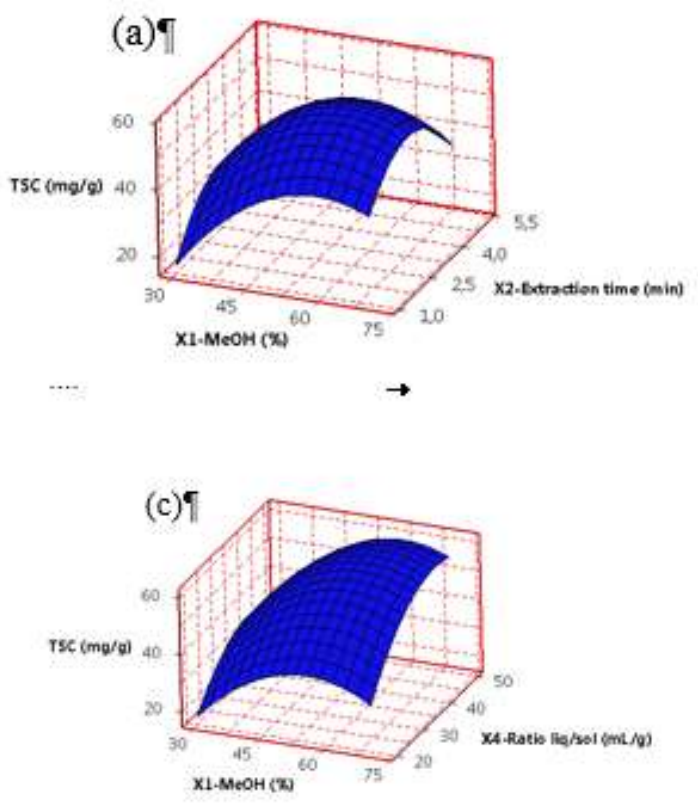

ฯ

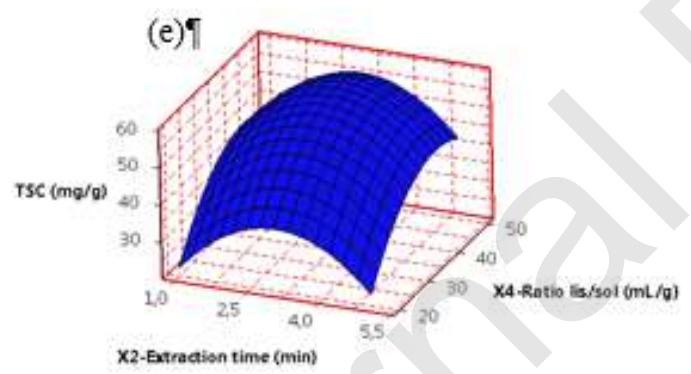

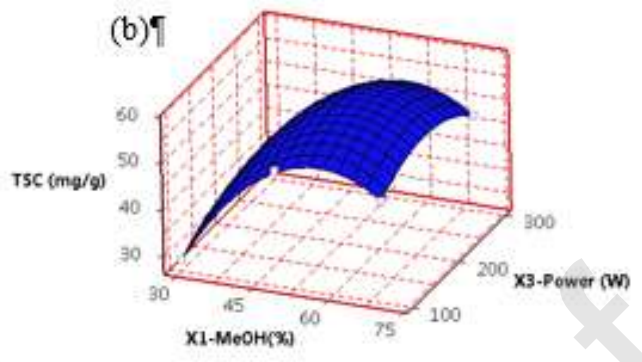

ฯ

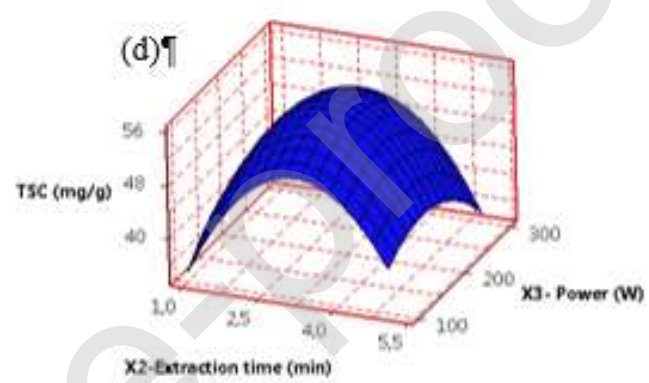

X2-Eatraction time (min)

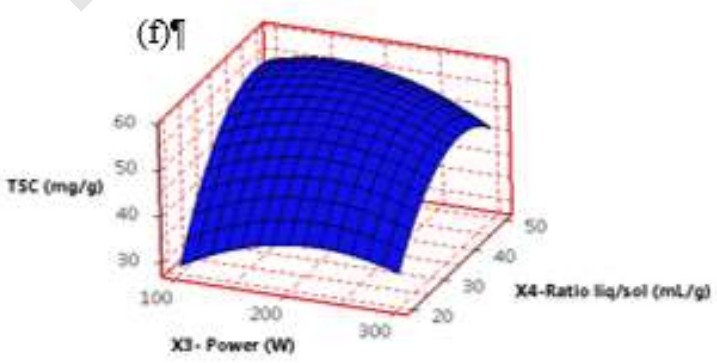

ฯ

Fig. 1. Response surface analysis for the total saponin compound from Echinaster sepositus by MAE with respect to (a): methanol percentage and irradiation time, (b): methanol percentage and microwave power, (c): methanol per percentage and ratio liquid to solid, (d) microwave power and irradiation time, (e): ratio liquid to solid and irradiation time, (f): microwave power and ratio liquid to solid. 


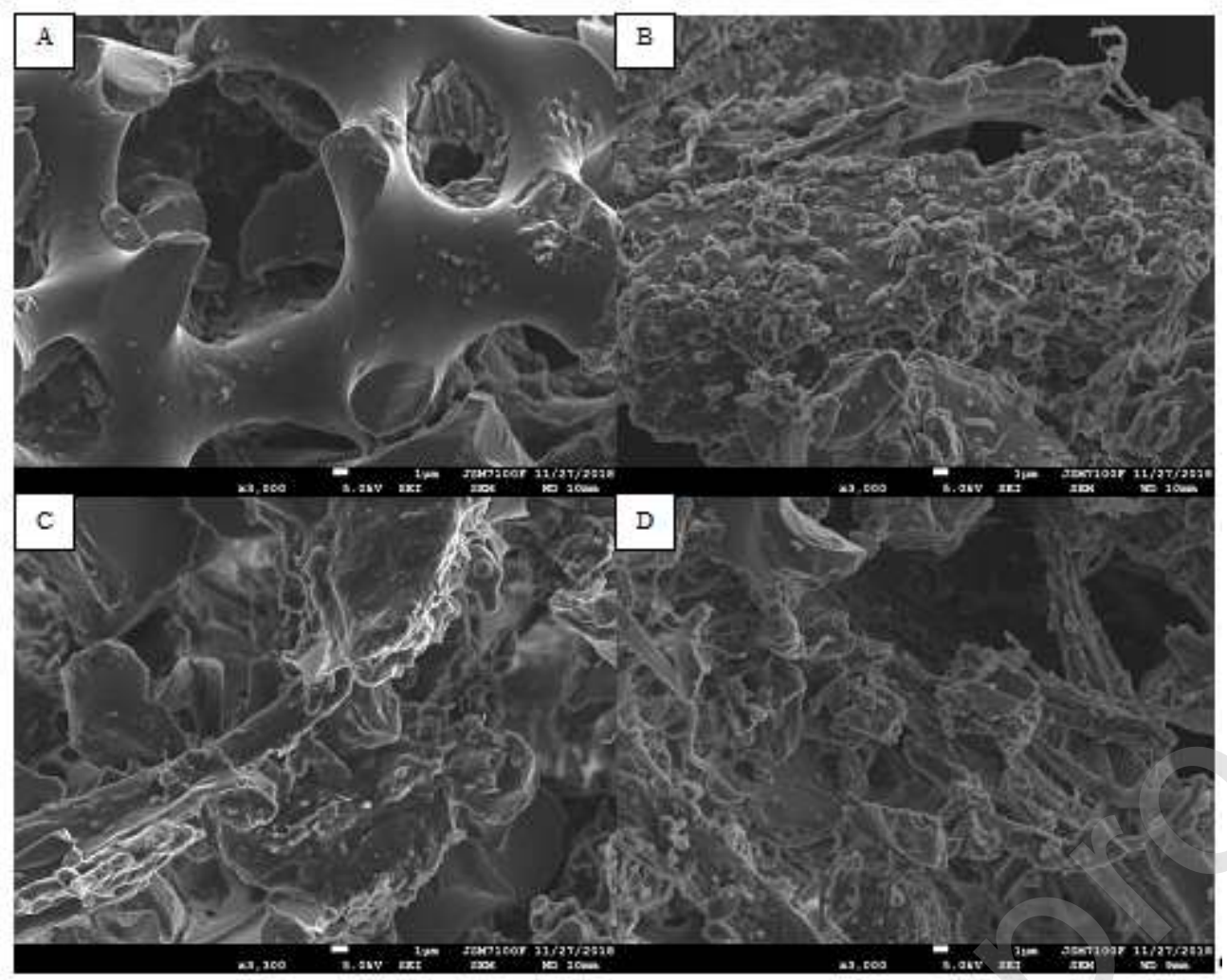

Fig. 2. Scanning electron microscope images of Echinaster sepositus powder before (A) and after extraction by conventional solvent extraction (B), ultrasound assisted extraction (C) and microwave assisted extraction (D).

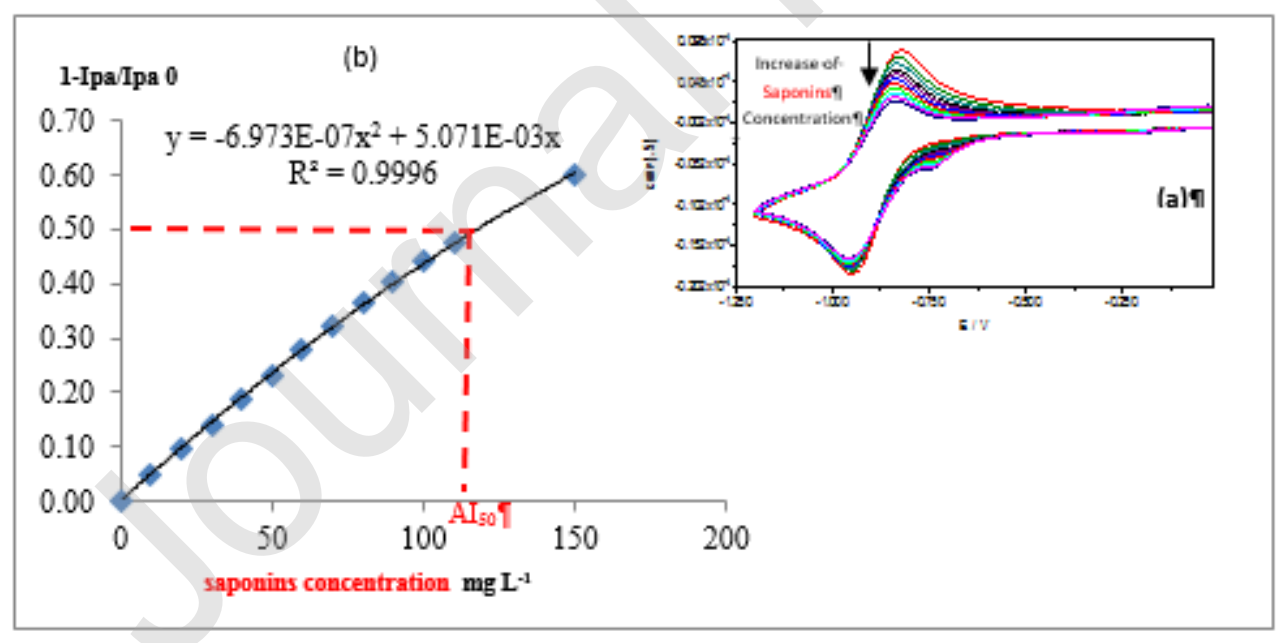

Fig. 3. Determination of $\mathrm{AI}_{50}$ for $\mathrm{MAE}$ saponins of Echinaster sepositus by cyclic voltammetry of $\mathrm{O}_{2}$ at a glassy carbon disk electrode in $\mathrm{DMF} / 0.1 \mathrm{M} \mathrm{Bu}_{4} \mathrm{NPF}_{6}$. Scan rate $0.1 \mathrm{Vs}^{-1}$. (a) Cyclic 
voltammograms with increasing saponins concentrations; (b) (1-Ipas/Ipa $)$ versus increasing concentrations of the saponins extract.

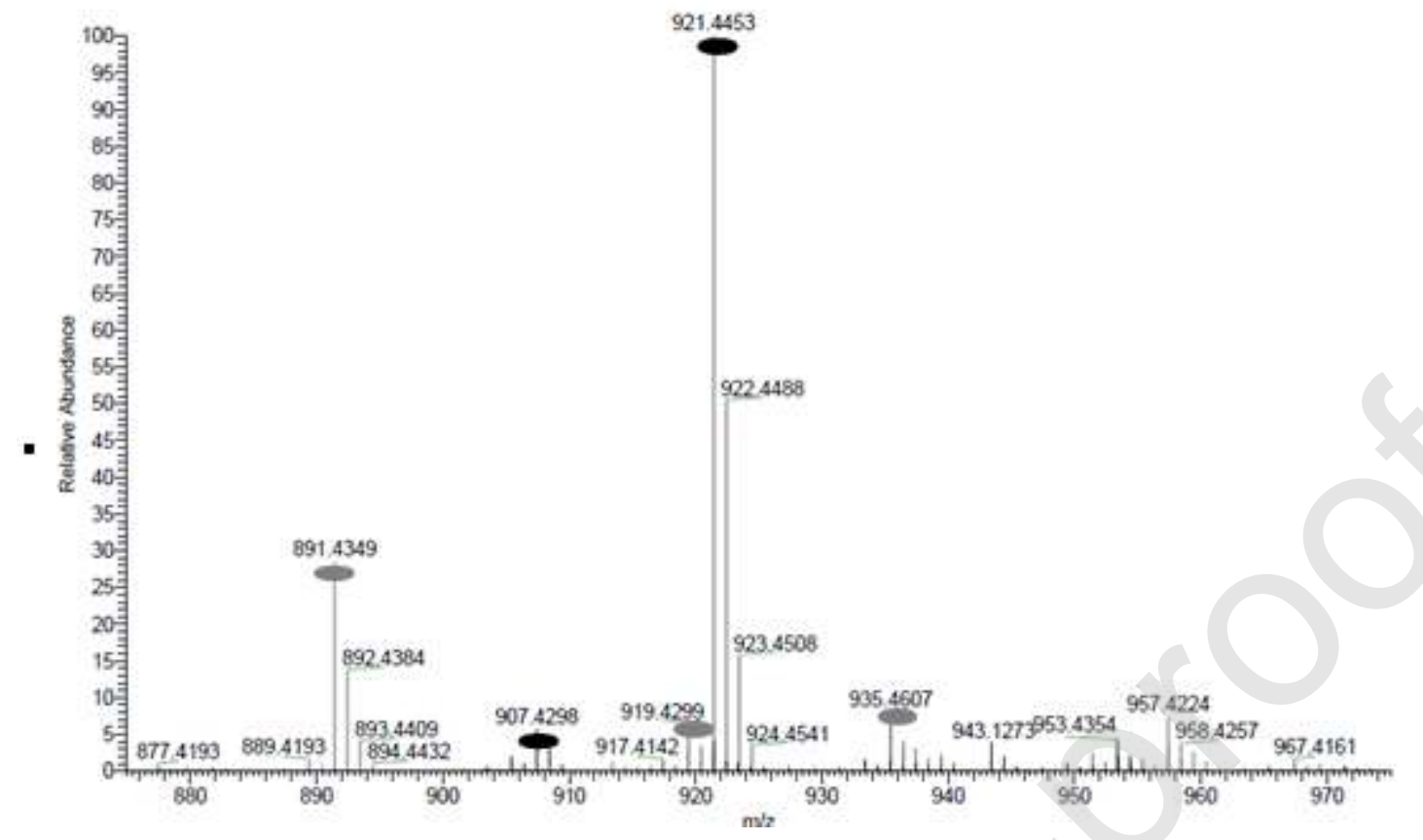

Fig. 4. ESI-MS mass spectrum (in the $\mathrm{m} / \mathrm{z} 800$ and 100 range) obtained for the MAE saponin extract from E. sepositus. MS signals marked by a black dot correspond to saponin congeners already identified in E. sepositus, while signals identified by gray dots could represent new saponins for this species.
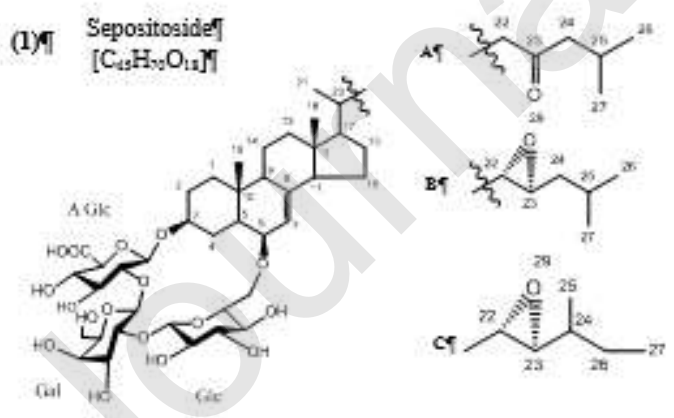

(2)

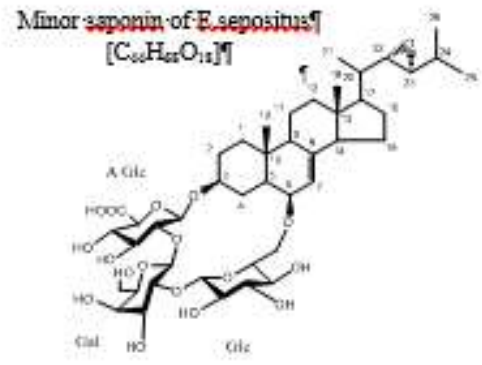

(3)
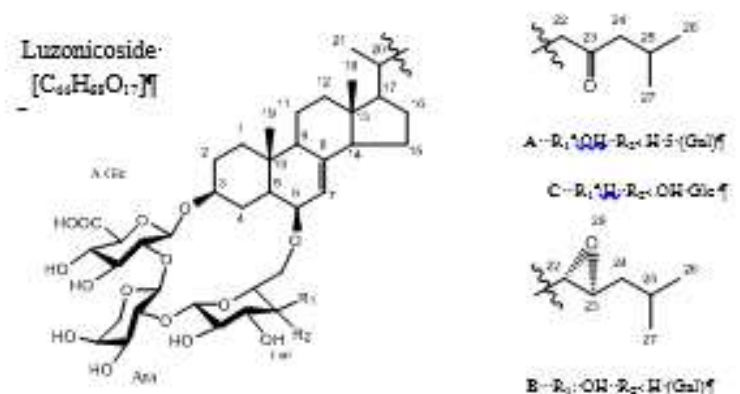

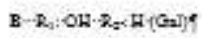


Fig. 5. Macrocycliques saponins of Echinaster sepositus ((1): A, B, C), minor saponin (2) of Echinastre sepositus [6, 7]; and luzonicoside ((2): A, B, C ) of Echinastre luzonicus [11, 26]. 


\section{Table1}

Table 1 Single-factor experiment results for MAE of saponins from E. sepositus. Results are reported as means $\pm \mathrm{SD}$. Same letters in the same column refer to means not statistically different according to ANOVA and Tukey's test. TSC, total saponin compound; $\mathrm{T}_{\text {sap }}$, saponin total; SP, starfish powder.

\begin{tabular}{|c|c|c|c|c|c|c|c|c|c|}
\hline \multicolumn{2}{|l|}{ Solvent } & \multicolumn{2}{|c|}{$\begin{array}{l}\text { Methanol } \\
\text { concentration } \\
(\%)\end{array}$} & \multicolumn{2}{|c|}{$\begin{array}{l}\text { Irradiation time } \\
(\mathrm{min})\end{array}$} & \multicolumn{2}{|c|}{$\begin{array}{l}\text { Microwave } \\
\text { power }(\mathrm{W})\end{array}$} & \multicolumn{2}{|c|}{$\begin{array}{l}\text { Liquid-to-solid ratio } \\
(\mathrm{mL} / \mathrm{g})\end{array}$} \\
\hline Type & $\begin{array}{l}\text { TSC } \\
\left(\mathrm{mg}_{\mathrm{Tsap}} / \mathrm{g}_{\mathrm{SP}}\right)\end{array}$ & $\begin{array}{l}\% \\
(\mathrm{~V} / \mathrm{V})\end{array}$ & $\begin{array}{l}\mathrm{TSC} \\
\left(\mathrm{mg}_{\mathrm{Tsap}} / \mathrm{g}_{\mathrm{SP}}\right)\end{array}$ & $\min$ & $\begin{array}{l}\mathrm{TSC} \\
\left(\mathrm{mg}_{\mathrm{Tsap}} / \mathrm{g}_{\mathrm{SP}}\right)\end{array}$ & W & $\begin{array}{l}\mathrm{TSC} \\
(\mathrm{mg} \\
\left.\mathrm{Tsa} / \mathrm{g}_{\mathrm{DM}}\right)\end{array}$ & $\mathrm{ml} / \mathrm{g}$ & $\begin{array}{l}\mathrm{TSC} \\
\left(\mathrm{mg}_{\mathrm{Tsap}} / \mathrm{g}_{\mathrm{SP}}\right)\end{array}$ \\
\hline 70\%МеОН & $\mathbf{2 4} \pm 0.00^{\mathrm{A}}$ & 20 & $8 \pm 0.00^{\mathrm{D}}$ & 1 & $39.89 \pm 0.18^{\mathrm{E}}$ & 100 & $39.79 \pm 0.18^{B}$ & 10 & $11.98 \pm 0.01^{\mathrm{D}}$ \\
\hline $70 \%$ EtOH & $\mathbf{1 9 . 6 6} \pm 0.57^{\mathrm{B}}$ & 30 & $13.33 \pm 2.30^{\mathrm{C}}$ & 2 & $48 \pm 0.00^{\mathrm{C}, \mathrm{B}}$ & 200 & $46.63 \pm 0.12^{\mathrm{A}}$ & 20 & $23.87 \pm 0.14^{\mathrm{C}}$ \\
\hline \multirow[t]{6}{*}{ Eau } & $12 \pm 0.00^{\mathrm{C}}$ & 40 & $18.66 \pm 0.30^{\mathrm{B}}$ & 3 & $55.85 \pm 0.26^{\mathrm{A}}$ & 300 & $32.35 \pm 0.20^{\mathrm{C}}$ & 30 & $36 \pm 0.25^{\mathrm{B}}$ \\
\hline & & 50 & $24 \pm 0.00^{\mathrm{A}}$ & 4 & $49.47 \pm 0.23^{\mathrm{B}}$ & 400 & $24.67 \pm 0.58^{\mathrm{D}}$ & 40 & $39.89 \pm 0.18^{\mathrm{A}}$ \\
\hline & & 60 & $24 \pm 0.00^{\mathrm{A}}$ & 5 & $42.97 \pm 0.20^{\mathrm{D}}$ & 500 & $16.14 \pm 0.47^{\mathrm{E}}$ & 50 & $39.48 \pm 0.45^{\mathrm{A}}$ \\
\hline & & 70 & $24 \pm 0.00^{\mathrm{A}}$ & 6 & $35.28 \pm 0.68^{\mathrm{F}}$ & & & & \\
\hline & & 80 & $24 \pm 0.00^{\mathrm{A}}$ & 8 & $22.34 \pm 0.10^{\mathrm{G}}$ & & & & \\
\hline & & 90 & $22.6 \pm 2.3^{\mathrm{A}}$ & & & & & & \\
\hline
\end{tabular}


Table 2

Box-Behnken design (BBD) with the observed responses and predicted values for yield of total saponin compounds (TSC) referred to starfish powder (SP) of E. sepositus using MAE.

\begin{tabular}{|c|c|c|c|c|c|c|}
\hline \multirow[t]{2}{*}{ Run } & \multirow{2}{*}{$\begin{array}{l}\mathrm{X}_{1}-\text { Methanol } \\
\text { concentration } \\
(\%, \mathrm{v} / \mathrm{v})\end{array}$} & \multirow{2}{*}{$\begin{array}{l}\mathrm{X}_{2} \text {-Irradiation } \\
\text { time }\end{array}$} & \multirow{2}{*}{$\begin{array}{l}\mathrm{X}_{3}-\text { Microwave } \\
\text { power }(\mathrm{W})\end{array}$} & \multirow{2}{*}{$\begin{array}{l}\mathrm{X}_{4-} \text { - Liquid-to- } \\
\text { solid ratio } \\
\left(\mathrm{mL} \mathrm{g}^{-1}\right)\end{array}$} & \multicolumn{2}{|c|}{ TSC $\left(\mathrm{mg}_{\text {sap }} / \mathrm{g}_{\mathrm{SP}}\right)$} \\
\hline & & & & & $\begin{array}{l}\text { Observed } \\
\text { responses }\end{array}$ & $\begin{array}{l}\text { Predicted } \\
\text { values }\end{array}$ \\
\hline 1 & 30 & 1 & 200 & 35 & $16.78 \pm 0.00$ & 16.75 \\
\hline 2 & 70 & 1 & 200 & 35 & $40.70 \pm 0.20$ & 40.59 \\
\hline 3 & 30 & 5 & 200 & 35 & $22.34 \pm 0.05$ & 22.43 \\
\hline 4 & 70 & 5 & 200 & 35 & $36.71 \pm 0.49$ & 36.73 \\
\hline 5 & 50 & 3 & 100 & 20 & $28.74 \pm 0.08$ & 28.70 \\
\hline 6 & 50 & 3 & 300 & 20 & $34.47 \pm 0.10$ & 34.32 \\
\hline 7 & 50 & 3 & 100 & 50 & $54.00 \pm 0.00$ & 54.13 \\
\hline 8 & 50 & 3 & 300 & 50 & $46.50 \pm 0.71$ & 46.52 \\
\hline 9 & 30 & 3 & 200 & 20 & $17.20 \pm 0.00$ & 17.17 \\
\hline 10 & 70 & 3 & 200 & 20 & $30.68 \pm 0.17$ & 30.93 \\
\hline 11 & 30 & 3 & 200 & 50 & $30.90 \pm 0.29$ & 30.68 \\
\hline 12 & 70 & 3 & 200 & 50 & $55.00 \pm 0.00$ & 55.06 \\
\hline 13 & 50 & 1 & 100 & 35 & $34.39 \pm 0.18$ & 34.39 \\
\hline 14 & 50 & 5 & 100 & 35 & $39.86 \pm 0.00$ & 39.78 \\
\hline 15 & 50 & 1 & 300 & 35 & $37.76 \pm 0.00$ & 37.87 \\
\hline 16 & 50 & 5 & 300 & 35 & $34.27 \pm 0.00$ & 34.30 \\
\hline 17 & 30 & 3 & 100 & 35 & $28.57 \pm 0.14$ & 28.67 \\
\hline 18 & 70 & 3 & 100 & 35 & $48.25 \pm 0.00$ & 48.14 \\
\hline 19 & 30 & 3 & 300 & 35 & $27.97 \pm 0.00$ & 28.07 \\
\hline 20 & 70 & 3 & 300 & 35 & $46.85 \pm 0.00$ & 46.75 \\
\hline 21 & 50 & 1 & 200 & 20 & $22.31 \pm 0.13$ & 22.33 \\
\hline 22 & 50 & 5 & 200 & 20 & $23.15 \pm 0.07$ & 23.12 \\
\hline 23 & 50 & 1 & 200 & 50 & $41.00 \pm 0.00$ & 41.03 \\
\hline 24 & 50 & 5 & 200 & 50 & $42.08 \pm 0.11$ & 42.06 \\
\hline 25 & 50 & 3 & 200 & 35 & $55.94 \pm 0.00$ & 55.94 \\
\hline 26 & 50 & 3 & 200 & 35 & $55.94 \pm 0.00$ & 55.94 \\
\hline 27 & 50 & 3 & 200 & 35 & $55.94 \pm 0.00$ & 55.94 \\
\hline
\end{tabular}


Table 3

Analysis of variance (ANOVA) for the experimental results obtained by MAE.

\begin{tabular}{llllll}
\hline Source & Sum of squares & Df & $F$-Value & $P$-Value & \\
\hline Model & 7612.25 & 14 & 14215.34 & 0.000 & Significant \\
X1-MeOH & 2182.33 & 1 & 57054.95 & 0.000 & \\
X2-Temps & 4.98 & 1 & 130.30 & 0.000 & \\
X3-Power & 5.98 & 1 & 156.45 & 0.000 & \\
X4-Ratio & 2125.11 & 1 & 55558.80 & 0.000 & \\
X1X2 & 45.56 & 1 & 1191.06 & 0.000 & \\
X1X3 & 0.32 & 1 & 8.34 & 0.006 & \\
X1X4 & 56.445 & 1 & 1475.90 & 0.000 & \\
X2X3 & 40.20 & 1 & 1051.04 & 0.000 & \\
X2X4 & 0.03 & 1 & 0.73 & 0.399 & \\
X3X4 & 87.49 & 1 & 2287.44 & 0.000 & \\
X1 & 1733.33 & 1 & 45316.06 & 0.000 & \\
X2 & 2112.45 & 1 & 55227.86 & 0.000 & \\
X3 & 298.24 & 1 & 7797.08 & 0.000 & \\
X4 & 1011.67 & 1 & 26449.19 & 0.000 & \\
Error & $\mathbf{1 . 4 9}$ & 39 & & & \\
Lack of fit & $\mathbf{0 . 4 9}$ & 10 & 1.43 & 0.215 & Not significant \\
Pur error & $\mathbf{1 . 0 0}$ & 29 & & & \\
Cor total & $\mathbf{7 6 1 3 . 7 4}$ & 53 & & & \\
$\mathrm{R}^{2}=0.9998$ & $\mathrm{R}^{2}$ adj=0.9997 & $\mathrm{R}^{2}$ pred=0.9996 & & \\
\hline
\end{tabular}

